\title{
Erratum to: A Study of Rural Church Health Promotion Environments: Leaders' and Members' Perspectives
}

\author{
Randi M. Williams • Karen Glanz • Michelle C. Kegler • \\ Ernest Davis Jr.
}

Published online: 29 December 2009

(C) Springer Science+Business Media, LLC 2009

\section{Erratum to: J Relig Health DOI 10.1007/s10943-009-9306-2}

In this article, there is a typo in the bio. The third sentence should say 'She has spent...'. Presently it says 'She have....'

The online version of the original article can be found under doi:10.1007/s10943-009-9306-2.

R. M. Williams $(\bowtie)$

Department of Oncology, Lombardi Comprehensive Cancer Center, Georgetown University Medical Center, 3300 Whitehaven Street, NW, Suite 4100, Washington, DC 20007, USA

e-mail: rmw27@georgetown.edu

K. Glanz

Schools of Medicine and Nursing, University of Pennsylvania, Philadelphia, PA, USA

M. C. Kegler

Emory Prevention Research Center, Rollins School of Public Health, Emory University, Atlanta, GA, USA

E. Davis Jr.

Bethel African Methodist Episcopal Church, Albany, GA, USA 